\title{
ASSESSING TPACK INTEGRATION IN SENIOR PHASE SCIENCE TEACHING AND LEARNING AT SOUTH AFRICAN TOWNSHIP SCHOOLS
}

\author{
Hlulani Shilenge, \& Sam Ramaila \\ Department of Science and Technology Education, University of Johannesburg (South Africa)
}

\begin{abstract}
As a complex dichotomy, the advent of the fourth industrial revolution poses enormous challenges while providing practical pedagogical benefits for science teaching and learning within the broader South African educational context. While the need to integrate technology as a catalyst for pedagogic innovation in science teaching and learning is paramount, considerable attention ought to be devoted to meaningful teacher professional development on the effective utilization of appropriate information and communication technology tools. In view of this key strategic imperative, this study primarily examined the effectiveness of the technological pedagogical content knowledge (TPACK) integration in Senior Phase science teaching and learning at selected South African township schools. The study adopted a generic qualitative design located within the interpretive research paradigm. Data was collected through semi-structured interviews and lesson observations involving three purposively selected Natural Sciences teachers at South African township schools. The study demonstrated that general lack of essential resources and appropriate technological skills hampered teachers' ability to meaningfully integrate TPACK in Senior Phase science teaching and learning at the selected South African township schools. In addition, teachers' lack of topic specific pedagogical content knowledge served as an impediment to effective integration of TPACK in Senior Phase science teaching and learning. Moreover, teachers' inability to identify and deploy appropriate information and communication technology tools reflected inadequate understanding of the TPACK framework. Implications for technology-enhanced learning are discussed.
\end{abstract}

Keywords: TPACK, technology-enhanced learning, pedagogic innovation.

\section{Introduction}

The implementation of technology-enhanced learning is a curriculum reform imperative which is in line with digital transformation in its broadest sense. The South African government is poised to introduce technology-based education in all schools with a view to provide every learner with digital workbooks and textbooks (Matiwane, 2019). Innovative use of technology in the classrooms to enhance meaningful learning remains an extremely difficult and complex undertaking for teachers (Webb \& Cox, 2004). Teachers find it increasingly difficult to integrate technology into their own teaching practices (Voogt \& McKenney, 2017). Yet, the integration of technology into teachers' pedagogical practices is vital for the enhancement of their pedagogical content knowledge. At another pragmatic level, the application of technology in the classroom for lesson presentation and assessment proved to be an arduous undertaking for teachers (Koehler \& Mishra, 2009).

According to Koehler and Mishra (2009), effective delivery of content using technology ought to be underpinned by a coherent blending of three key components, namely, content, pedagogy and technology. These components constitute the Technological Pedagogical Content Knowledge (TPACK) framework proposed by Koehler and Mishra (2009). The TPACK framework is essentially an extension of Shulman's (1987) conceptualization of the pedagogical content knowledge construct and serves to underscore the significance of various lesson presentations and concomitant key ingredients required to deliver effective lessons (Harris \& Hofer, 2011). There is a critical need to address the pervasive disjuncture between content-based curriculum and technology-enhanced learning. To this end, the TPACK framework can serve as a specialized way of effectively integrating technology into content-based curriculum (Harris \& Hofer, 2011). Given the crucial need to implement technology-enhanced learning with a view to foster pedagogic innovation, this study explored TPACK integration in Senior Phase science teaching and learning at South African township schools. 


\section{Research design and methodology}

This study adopted a generic qualitative design located within the interpretive research paradigm. Qualitative design was appropriate for this study as it provides rich data in respect of a phenomenon or context and provides an understanding of the factors being observed (McLeod, 2017). In addition, qualitative research provides multiple perspectives and makes it possible for the issue under empirical investigation to be studied in greater detail. Data was collected through semi-structured interviews and lesson observations involving three purposively selected Natural Sciences teachers at South African township schools. Analysis of qualitative data was guided by the Coding Manual for Qualitative Researchers developed by Saldana (2009).

\section{Findings}

The study involved three Natural Sciences teachers as participants. The demographic profile of the participants is provided in Table 1 below.

Table 1. Demographic profile of the participants.

\begin{tabular}{|l|c|c|c|l|}
\hline & Gender & Age & Teaching experience & \multicolumn{1}{|c|}{ Qualifications } \\
\hline Teacher A & Male & 52 years & 24 years & $\begin{array}{l}\text { College Diploma } \\
\text { Advanced Certificate } \\
\text { in Education }\end{array}$ \\
\hline Teacher B & Male & 30 years & 6 years & University Degree \\
\hline Teacher C & Female & 30 years & 3 years & University Degree \\
\hline
\end{tabular}
analysis.

The key findings in this study are clustered according to the themes that emerged during data

\subsection{Theme 1: Resources and skills required to integrate TPACK in Senior Phase science teaching and learning}

Analysis of data obtained from lesson observations revealed that teachers at selected township schools investigated do not have relevant resources required to integrate TPACK in Senior Phase science teaching and learning. Out of the three schools observed, only one school had an interactive white board and a white board with no additional technological devices. The participants indicated that they do not have the skills required for meaningful technology integration in science teaching and learning. The following excerpt captures the sentiment expressed by Teacher A.

I do not have knowledge of the use of technologies in teaching and learning and I never received training about the use of technology for teaching and learning.

This sentiment was corroborated by Teacher B who also expressed frustration about the lack of relevant resources required for meaningful technology integration in science teaching and learning as encapsulated in the following excerpt.

There are few resources in my classroom and I do not have adequate knowledge of the use of those resources in teaching and learning.

Figure 1 below provides a depiction of teachers' rating on a scale of $0-4$ of the various aspects investigated. Lack of resources and appropriate technological skills appeared to have a detrimental impact on meaningful integration of TPACK in Senior Phase science teaching and learning as evidenced by the teachers' rating of the various aspects investigated. Thus, it is imperative for the South African Department of Basic Education to provide requisite resources while ensuring that appropriate technological training for teachers is provided in a sustainable manner. This implies that deployment of resources ought to be accompanied by provision of relevant technological training required to facilitate the integration of technology in Senior Phase science teaching and learning in particular. 
Figure 1. Teachers' rating of the various aspects investigated.

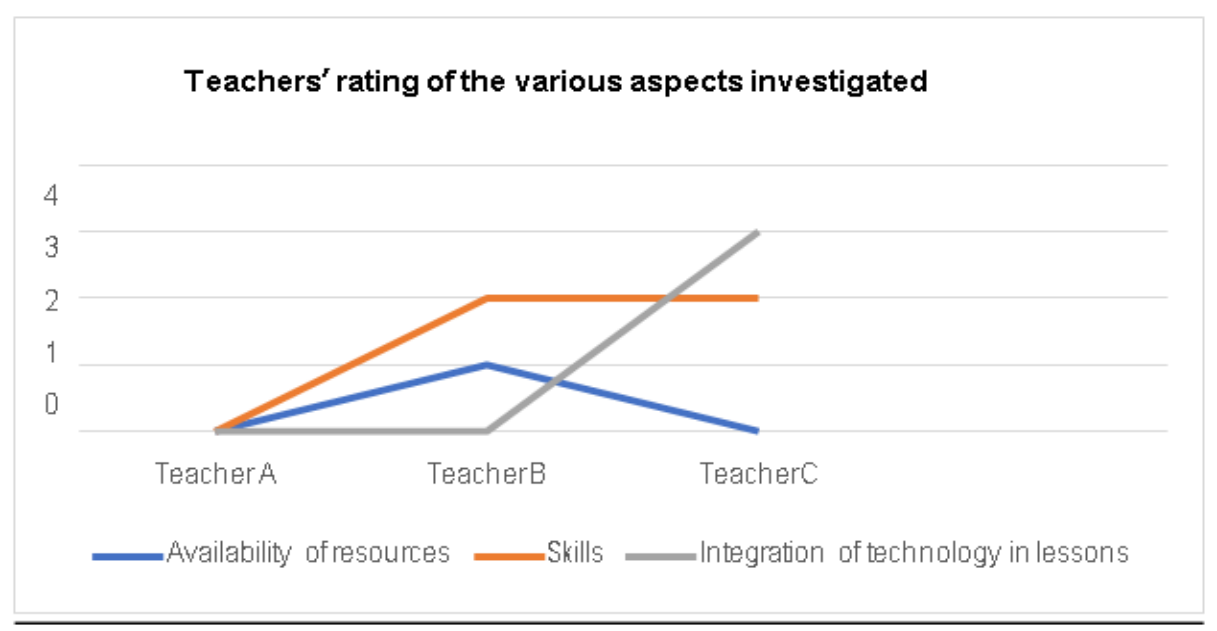

\subsection{Theme 2: Overall understanding of TPACK framework}

The teachers demonstrated adequate mastery of content knowledge. However, their pedagogical content knowledge appeared to be inadequate. The three teachers detailed how they use pedagogical illustrations and content representations during their lessons to ensure learners understand the content without enacting inquiry-based learning as a contemporary pedagogic approach. In essence, teachers experienced difficulties with the implementation of the pedagogical content knowledge (PCK) framework as evidenced by the sentiment expressed by Teacher A encapsulated in the following excerpt.

I have no knowledge of the PCK framework and could not recall having ever heard of the term before.

The selection of appropriate ICT tools to teach specific topics proved increasingly difficult for teachers. The manifestation of this challenge is reflected in the sentiments expressed by Teacher A as encapsulated in the following excerpt.

I do not have an idea of any kind of technology that can be integrated into my lessons when teaching the solar system for instance. I never integrate any technology when teaching the solar system, I only show learners a model of the earth.

The teachers portrayed inadequate technological knowledge which is exacerbated by severe lack of essential resources. In addition, lack of appropriate technological skills served to impede meaningful integration of TPACK in Senior Phase science teaching and learning. Figure 2 below reflects teachers' rating of their own professional competence in terms of TPACK framework on a scale of $0-5$.

Figure 2. Teachers' rating of their own professional competence in terms of TPACK framework.

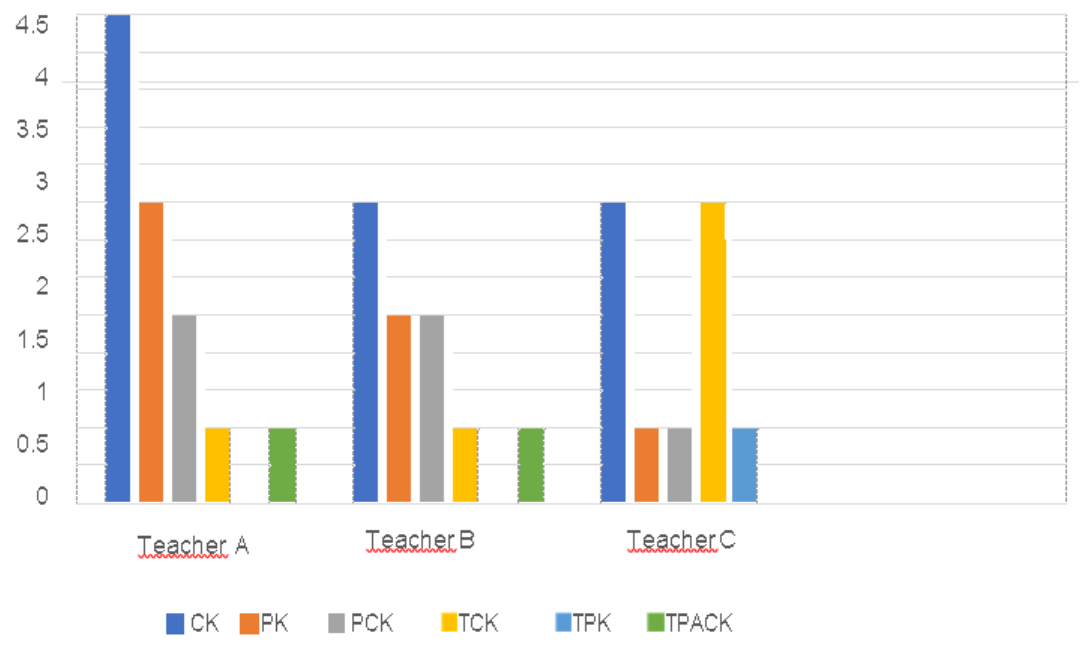




\section{Discussion}

This study revealed that teachers at selected South African township schools do not have relevant resources required to integrate TPACK in Senior Phase science teaching and learning at their disposal. General lack of essential resources and appropriate technological skills appeared to have a detrimental impact on meaningful integration of TPACK in Senior Phase science teaching and learning. This finding is consistent with a study conducted by Alhababi (2017) which demonstrated that meaningful teaching and learning is adversely affected by limited availability of technological resources and appropriate technological skills to use these resources. This state of affairs is exacerbated by the fact that availability of technological resources in rural schools is not always supported by the provision of internet access (Madangopal \& Madangopal, 2018). It has also been established that limited internet access serves to stifle effective implementation of TPACK framework in rural schools (Ghavifekr, Kunjappan, Ramasamy, Anthony, 2016). In addition, Nkula and Krauss (2014) identified lack of access to resources as one of the main barriers to ICT integration.

The teachers demonstrated adequate mastery of content knowledge although their pedagogical content knowledge was not firmly established. The teachers portrayed inadequate technological knowledge which appeared to be exacerbated by severe lack of essential resources. Furthermore, lack of appropriate technological skills served to impede meaningful integration of TPACK in Senior Phase science teaching and learning. In this regard, Dalal, Archambault and Shelton (2017) posit that teachers with adequate technological pedagogical knowledge often encounter challenges with the integration of technological content knowledge in teaching and learning. In support of this notion, Chai, Koh and Tsai (2013) maintain that the complex disjuncture between technology integration and content-based curriculum remains a fundamental challenge to teachers.

The selection and deployment of appropriate ICT tools to teach specific topics appeared to be an arduous task for teachers. As observed by Koehler, Mishra, Kereluik, Shin and Graham (2014), most teachers cannot select appropriate technological applications to use as they lack sufficient knowledge on how to integrate these applications into their lessons. Technology integration poses significant challenges to teachers at each level of the school system (Johnson, Jacovina, Russel \& Soto, 2016). Ramorola (2010) noted that the effectiveness of ICT integration is crucially dependent on teachers' ability to use technology. The challenges encountered by teachers in relation to technology integration in Senior Phase science teaching and learning ought to be addressed as an integral part of sustainable teacher professional development interventions. As a member of the global community of nations, South Africa is faced with the key strategic imperative to provide a globally competitive curriculum in order to ensure sustainable enhancement of human capacity development.

\section{Conclusion}

The integration of TPACK in Senior Phase science teaching and learning remains a fundamental challenge for teachers at South African township schools within the context of this study. There is a crucial need to create increased opportunities for teachers to fully embrace technology integration as a key curriculum reform imperative for purposes of fostering meaningful development of scientific literacy. This mission can be accomplished by harnessing the practical pedagogic benefits associated with the advent of the fourth industrial revolution as a game changer.

\section{References}

Alhababi, H.H. (2017). Technological Pedagogical Content Knowledge (TPACK) Effectiveness on English Teachers and Students in Saudi Arabia. Dissertations. 456.

Chai, C.S., Koh, J.H.L., \& Tsai, C.C. (2013). Examining practicing teachers' perceptions of Technological Pedagogical Content Knowledge (TPACK) pathways: A structural equation modelling approach. Instructional Science: An International Journal of the Learning Sciences, 41(4), 793-809.

Dalal, M., Archambault, L., \& Shelton, C. (2017). Professional development for international teachers: Examining TPACK and technology integration. Journal of Research on Technology in Education, 49(3-4), 117-133.

Ghavifekr, S., Kunjappan, T., Ramasamy, L., \& Anthony, A. (2016). Teaching and Learning with ICT Tools: Issues and challenges from teachers' perceptions. Malaysian Online Journal of Educational Technology, 4(2), 38-57. 
Harris, J.B., \& Hofer, M.J. (2011). Technological pedagogical content knowledge (TPACK) in action: A descriptive study of secondary teachers' curriculum-based, technology-related instructional planning. Journal of Research on Technology in Education, 43(3), 211-229.

Johnson, A. M., Jacovina, M. E., Russell, D. E., \& Soto, C. M. (2016). Challenges and solutions when using technologies in the classroom. In S. A. Crossley \& D. S. McNamara (Eds.) Adaptive Educational Technologies for Literacy Instruction (pp. 13-29).

Koehler, M.J., \& Mishra, P. (2009). What is technological pedagogical content knowledge? Contemporary Issues in Technology and Teacher Education, 9(1), 60-70.

Koehler, M. J., Mishra, P., Kereluik, K., Shin, T. S., \& Graham, C. R. (2014). The technological pedagogical content knowledge framework. In J. Spector, M. Merrill, J. Elen, \& M. Bishop (Eds.), Handbook of Research on Educational Communications and Technology (pp. 101-111). New York, NY: Springer.

Madangopal, D., \& Madangopal, M. (2018). ICT in education: The rural challenge. Centre for Communication and Development Studies.

Matiwane, Z. (2019). Public schools to go digital within six years: Cyril Ramaphosa. Times Live, p1.

McLeod, S. (2017). Qualitative vs Quantitative Research. Simply Psychology.

Nkula, K., \& Krauss, K.E.M. (2014). The integration of ICT in marginalized schools in South Africa: Considerations for understanding the perceptions of in-service teachers and the role of planning. International Development Informatics Association Conference, South Africa (pp. 241-261).

Ramorola, N.Z. (2010). A study of effective technology integration into teaching and learning: A case study, University of South Africa, Pretoria.

Saldana, J. (2009). The Coding Manual for Qualitative Researchers. London: SAGE Publications.

Shulman, L.S. (1987). Knowledge and teaching: Foundations of the new reform. Harvard Education Review, 57(1), 1-22.

Voogt, J., \& McKenney, S. (2017). TPACK in teacher education: Are we preparing teachers to use technology for early literacy? Technology, Pedagogy and Education, 26(1), 69-83.

Webb, M., \& Cox, M. (2004). A review of pedagogy related to information and communications technology. Technology, Pedagogy and Education, 13, 235-286. 